\title{
Haemodynamic effects of phentolamine in chronic obstructive pulmonary disease
}

\author{
Lawrence Gould, Mohammad Zahir, Anthony DeMartino, and Robert F. Gomprecht \\ From the Medical Service of Misericordia-Fordham Hospital Affiliation, \\ Bronx, New York 10466, U.S.A.
}

Ten patients with chronic obstructive pulmonary disease without complicating cor pulmonale were studied by right and left heart catheterization. Respiratory and haemodynamic observations were made during a control period and during the infusion of phentolamine. Phentolamine produced a significant reduction in mean pulmonary artery pressure from $18.8 \mathrm{mmHg}$ to $13.1 \mathrm{mmHg}$, right ventricular end-diastolic pressure from $\mathrm{I} .8 \mathrm{mmHg}$ to $0 . \mathrm{I} \mathrm{mmHg}$, and left ventricular end-diastolic pressure from $8.2 \mathrm{mmHg}$ to $1.9 \mathrm{mmHg}$. The mean brachial artery pressure, cardiac index, and pulmonary vascular resistance were essentially unchanged. It is concluded that the haemodynamic response of the patients to phentolamine cannot be explained by a single mechanism. Multiple actions of the drug must be considered, including active pulmonary vasodilatation, and a positive inotropic action upon the heart.

The administration of phentolamine at an infusion rate of $0.3 \mathrm{mg} / \mathrm{min}$ to patients in congestive heart failure produces a striking haemodynamic improvement. The cardiac output, cardiac rate, systemic pressure, and stroke index increase while the pulmonary artery pressure, systemic peripheral resistance, left ventricular end-diastolic pressure, and left ventricular end-diastolic volume fall (Gould, Zahir, and Ettinger, 1969). Further, this conspicuous improvement of cardiac dynamics occurs within minutes, and is not associated with any untoward side effects.

Taylor et al. (1965a) studied the pulmonary circulation in normal and hypertensive patients before and after the acute intravenous injection of $5 \mathrm{mg}$ phentolamine. The drug caused a prompt reduction in the right atrial, pulmonary arterial, systemic arterial, and wedge pressures. The cardiac output was invariably increased while the pulmonary vascular resistance was decreased. They concluded that the predominant vascular activity of the drug was to cause a direct relaxation of the vascular smooth muscle, affecting not only the systemic resistance vessels but also the pulmonary and systemic venous circulation.

Phentolamine has an antispasmodic action in the isolated guinea-pig lung (Wiśniewska, I964). In addition, it has recently been shown

Received 3 July r970. that a significant improvement in pulmonary function tests occurs in normal man, as well as in patients with pulmonary emphysema, when a nebulizer containing $5 \mathrm{mg}$ phentolamine in I $\mathrm{ml}$ water is used (Gould and Dilieto, 1970).

These observations led us to consider the use of phentolamine in chronic pulmonary disease. We now report the effects of an intravenous infusion of phentolamine in patients with chronic obstructive pulmonary disease without cor pulmonale.

\section{Patients and method}

Ten patients with chronic bronchitis or obstructive pulmonary emphysema, or both, without complicating cor pulmonale were studied. All patients had normal heart size on radiological examination and normal electrocardiograms. There was no clinical evidence of coronary or valvular heart disease and none had diastolic hypertension. Their physical characteristics and pulmonary function tests are shown in Table $I$. All patients were able to lie supine with one pillow for the $2 \frac{1}{2}$-hour study period, and none was in acute respiratory distress. Studies were performed in the fasting, post-absorptive state without premedication.

Catheterization of the left ventricle was performed by retrograde arterial catheterization through a brachial arteriotomy. A Cournand needle was placed into the opposite brachial artery. To ensure high fidelity tracings, the needle was directly connected to a Statham pressure transducer, model P23 Db. A No. 7 Goodale 
TABLE I Pulmonary function studies in Io patients with chronic obstructive pulmonary disease

\begin{tabular}{|c|c|c|c|c|c|c|c|c|c|}
\hline $\begin{array}{l}\text { Case } \\
\text { No. }\end{array}$ & Sex & $\begin{array}{c}\text { Age } \\
(y r)\end{array}$ & $\begin{array}{l}\text { Body } \\
\text { surface } \\
\text { area }\end{array}$ & $\begin{array}{l}\text { Vital } \\
\text { capacity } \\
\text { (ml) } \\
\text { Control }\end{array}$ & Phen & $F E V_{1 \cdot 0}$ & Phen & 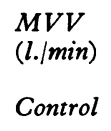 & Phen \\
\hline I & $\mathrm{F}$ & 38 & $I \cdot 56$ & $\begin{array}{c}2730 \\
(2970)\end{array}$ & 2570 & $\begin{array}{c}12 \\
(83)\end{array}$ & 9 & $\begin{array}{c}48 \\
(83)\end{array}$ & 34 \\
\hline 2 & $\mathbf{M}$ & 60 & $\mathrm{I} \cdot 86$ & $\begin{array}{c}3700 \\
(4380)\end{array}$ & & $\begin{array}{c}51 \\
(83)\end{array}$ & & $\begin{array}{c}55 \\
(79)\end{array}$ & \\
\hline 3 & $M$ & 50 & $I \cdot 75$ & $\begin{array}{c}2620 \\
(3740)\end{array}$ & 2580 & $\begin{array}{c}38 \\
(83)\end{array}$ & 32 & $\begin{array}{c}4 \mathrm{I} \\
(100)\end{array}$ & $4 I$ \\
\hline 4 & $\mathrm{~F}$ & 32 & $I \cdot 70$ & $\begin{array}{l}1360 \\
(3410)\end{array}$ & 1420 & $\begin{array}{c}38 \\
(83)\end{array}$ & 40 & $\begin{array}{c}16 \\
(90)\end{array}$ & 22 \\
\hline 5 & $\mathbf{M}$ & 72 & $I \cdot 68$ & $\begin{array}{c}2920 \\
(3440)\end{array}$ & 3100 & $\begin{array}{c}32 \\
(83)\end{array}$ & 28 & $\begin{array}{c}37 \\
(77)\end{array}$ & 35 \\
\hline 6 & $\mathbf{M}$ & 62 & $1 \cdot 56$ & $\begin{array}{c}2760 \\
(3740)\end{array}$ & & $\begin{array}{c}52 \\
(83)\end{array}$ & & $\begin{array}{c}48 \\
(67)\end{array}$ & \\
\hline 7 & $\mathbf{M}$ & 62 & $I \cdot 60$ & $\begin{array}{c}2325 \\
(3400)\end{array}$ & 2510 & $\begin{array}{c}18 \\
(83)\end{array}$ & 22 & $\begin{array}{l}19 \\
\text { (9I) }\end{array}$ & 26 \\
\hline 8 & $\mathbf{M}$ & 70 & $I \cdot 73$ & $\begin{array}{c}2820 \\
(3400)\end{array}$ & & $\begin{array}{c}55 \\
(83)\end{array}$ & & $\begin{array}{c}24 \\
(83)\end{array}$ & \\
\hline 9 & $\mathbf{M}$ & $2 I$ & $\mathrm{I} \cdot 78$ & $\begin{array}{c}4660 \\
(4620)\end{array}$ & & $\begin{array}{c}26 \\
(83)\end{array}$ & & $\begin{array}{r}74 \\
(\mathrm{I} 36)\end{array}$ & \\
\hline I0 & $\mathbf{F}$ & 25 & $I \cdot 72$ & $\begin{array}{c}4280 \\
(3500)\end{array}$ & & $\begin{array}{c}53 \\
(83)\end{array}$ & & $\begin{array}{c}66 \\
(103)\end{array}$ & \\
\hline
\end{tabular}

$\mathrm{FEV}_{1.0}=$ forced expiratory volume $-\mathrm{I}$ second; $\mathrm{MVV}=$ maximum voluntary ventilation (BTPS); figures in parenthesis indicate predicted values.

Lubin catheter was placed in the pulmonary artery. Cardiac output was determined in duplicate by the Fick technique. Oxygen consumption was determined by measuring ventilation with a Tissot spirometer, and analysing the expired gas with a Micro-Scholander apparatus. Mixed venous blood was obtained from the pulmonary artery and arterial blood from the brachial artery. Arterial and mixed venous oxygen contents were determined by the method of Van Slyke and Neill. Arterial blood gases and $p H$ were measured with the $p H / g a s$ analyser manufactured by Instrumentation Laboratories. Left ventricular, pulmonary arterial and systemic arterial pressures, and cardiac output were measured in the resting state. All pressures were obtained using the midthoracic level as the reference point.

Phentolamine was then infused intravenously at $0.3 \mathrm{mg} /$ minute. Pressures and cardiac output were measured 15 minutes after the onset of the infusion.

Ventricular function was assessed according to the following parameters:

(I) $\mathrm{LVSW}=\mathrm{LV}_{\mathrm{S}}-\mathrm{LV}_{\mathrm{D}} / 100 \times \mathrm{SI} \times \mathrm{I} \cdot 36 \times \mathrm{I} \cdot 050$

(2) $\mathrm{RVSW}=\mathrm{RV}_{\mathrm{S}}-\mathrm{RV}_{\mathrm{D}} / \mathrm{100} \times \mathrm{SI} \times \mathrm{I} \cdot 36 \times \mathrm{I} \cdot 050$

(3) $\mathrm{TPR}=\mathrm{BAm} \times 1332 / \mathrm{CO}$

(4) $\mathrm{PVR}=\mathrm{PAm}-\mathrm{LV}_{\mathrm{D}} \times 1332 / \mathrm{CO}$

Where LVSW = left ventricular stroke work $\left(\mathrm{g} \mathrm{m} /\right.$ beat per $\mathrm{m}^{2}$ body surface area);

$\mathrm{SI}=$ stroke index $\left(\mathrm{ml} /\right.$ beat per $\mathrm{m}^{2}$ body surface area);

$L_{\mathbf{s}}=$ mean left ventricular systolic pressure (mmHg);

$L V_{D}=$ left ventricular end-diastolic pressure $(\mathrm{mmHg})$;

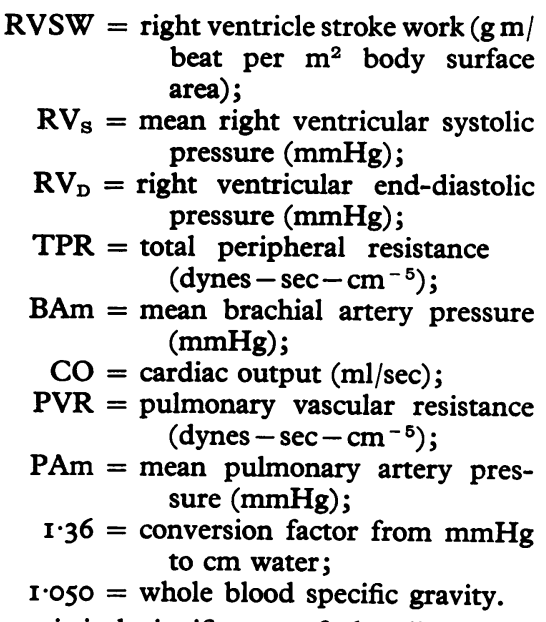

The statistical significance of the differences ( $P$ values) between the control values and phentolamine values was calculated with the Student $t$ test.

Five of the catheterized patients subsequently received phentolamine at an infusion rate of 0.3 $\mathrm{mg} /$ minute for 15 minutes. This was performed in order to measure the vital capacity, maximum voluntary ventilation, and the one second forced expiratory volume before and after phentolamine.

\section{Results}

Complete data on all ro patients are presented in Table 2. A summary and statistical analysis of the various parameters during the control period and during the phentolamine infusion are included in this Table. 
Observations at rest Four patients had pulmonary artery systolic pressures exceeding $30 \mathrm{mmHg}$. No patient had an abnormal increase in the right or left ventricular enddiastolic pressure. The cardiac index was within normal limits $\left(2.5\right.$ to $3.51 . / \mathrm{min}$ per $\left.\mathrm{m}^{2}\right)$ in 8 patients, low in 1 , and high in 1 . The partial pressure of carbon dioxide was above normal (46 mmHg) in I patient (Case 5), and the arterial oxygen saturation was below nor$\mathrm{mal}(92 \%)$ in 3 patients.

Phentolamine infusion The pulmonary artery systolic, diastolic, and mean pressures, the right ventricular end-diastolic pressure, and the left ventricular end-diastolic pressure fell in each patient. When the control values are compared to the values during the phentolamine infusion, the average pulmonary artery mean pressure decreased from 18.8 $\mathrm{mmHg}$ to $13.1 \mathrm{mmHg}(\mathrm{P}<0.01)$. The average right ventricular systolic pressure fell from 29.6 to $19.7 \mathrm{mmHg}(\mathrm{P}<0.01)$, while the average right ventricular end-diastolic pressure fell from I. 8 to $0 . \mathrm{I} \mathrm{mmHg}(\mathrm{P}<0.02)$. The average left ventricular end-diastolic pressure fell from 8.2 to $\mathrm{I} .9 \mathrm{mmHg}(P<0.00 \mathrm{r})$. The brachial artery pressure showed no significant change. The intracardiac pressures were measured 60 minutes after the onset of the infusion and were comparable to the I5-minute values.

The cardiac index, stroke index, heart rate, oxygen consumption, and arteriovenous oxygen difference did not reveal any significant change during the phentolamine infusion.

The average calculated total peripheral resistance and pulmonary vascular resistance fell minimally during the infusion. The average left ventricular stroke work increased while the average right ventricular stroke work decreased during the infusion. The changes were not statistically significant.

During the administration of phentolamine the minute ventilation increased significantly from 5.34 to $6.661 . / \mathrm{min}$ per $\mathrm{m}^{2}(\mathbf{P}<0.05)$. There was no significant change in the arterial blood $\mathrm{pH}$ or in the average arterial oxygen saturation. The oxygen and carbon dioxide tension in arterial blood also showed minimal changes.

The pulmonary function studies showed little change after the administration of phentolamine.

\section{Discussion}

All the patients studied had clinical evidence of chronic obstructive pulmonary disease. The pulmonary function tests showed variable degrees of impairment though all the patients showed moderate to severe impairment of the maximum voluntary ventilation.

All the patients studied had essentially normal haemodynamic findings before phentolamine administration, so that any directly measured changes produced by the drug must of necessity be small. Moreover, derived data suffer from compounding such small changes. During the infusion of phentolamine there was a significant reduction in the filling pressures of both ventricles and the mean pressures in the pulmonary artery. There was no appreciable change in the cardiac index or systemic arterial pressure. These haemodynamic changes can probably be explained by the recently described inotropic action of the drug.

The administration of $5 \mathrm{mg}$ phentolamine intravenously to normal dogs, each with a strain gauge arch attached to the right ventricle, will increase the ventricular contractile force (Gould et al., 1969). This positive inotropic response in animals has also been seen in humans by employing the left ventricular $\mathrm{dp} / \mathrm{dt}$ (Gould et al., I969). This measurement is much increased after the administration of phentolamine. This improvement in cardiac function may be explained by the recent observations of Dairman et al. (1968). They administered phentolamine $(5 \mathrm{mg} / \mathrm{kg})$ to rats. At the height of alpha-receptor blockade, the conversion of a tracer dose of tyrosine $-{ }^{14} \mathrm{C}$ to norepinephrine in the heart, brain, and adrenal gland was increased threefold with no alteration in specific activity of tyrosine in blood and tissues. From these studies, Dairman concluded that receptor blockade led to increased synthesis and release of norepinephrine in three organs that were measured. Our studies with smaller doses of phentolamine have indicated a positive inotropic effect. In view of the findings of Dairman and his co-workers, it could reasonably be assumed that the inotropic effect results from increased production of catecholamines in the myocardium. This contention has received support from the recent work of Bagwell et al. (I970). They administered $5 \mathrm{mg} / \mathrm{kg}$ of phentolamine to 7 experimental animals and observed an increase in the left ventricular contractile force. If the animals were pretreated with reserpine, phentolamine's inotropic action could be blocked. A subsequent infusion of norepinephrine could then restore the positive inotropic effect of phentolamine. The authors concluded that the positive inotropic action of phentolamine was dependent on the release of norepinephrine.

Taylor et al. (1965a) administered $5 \mathrm{mg}$ phentolamine intravenously to normal and 
TABLE 2 Haemodynamic and respiratory responses to phentolamine

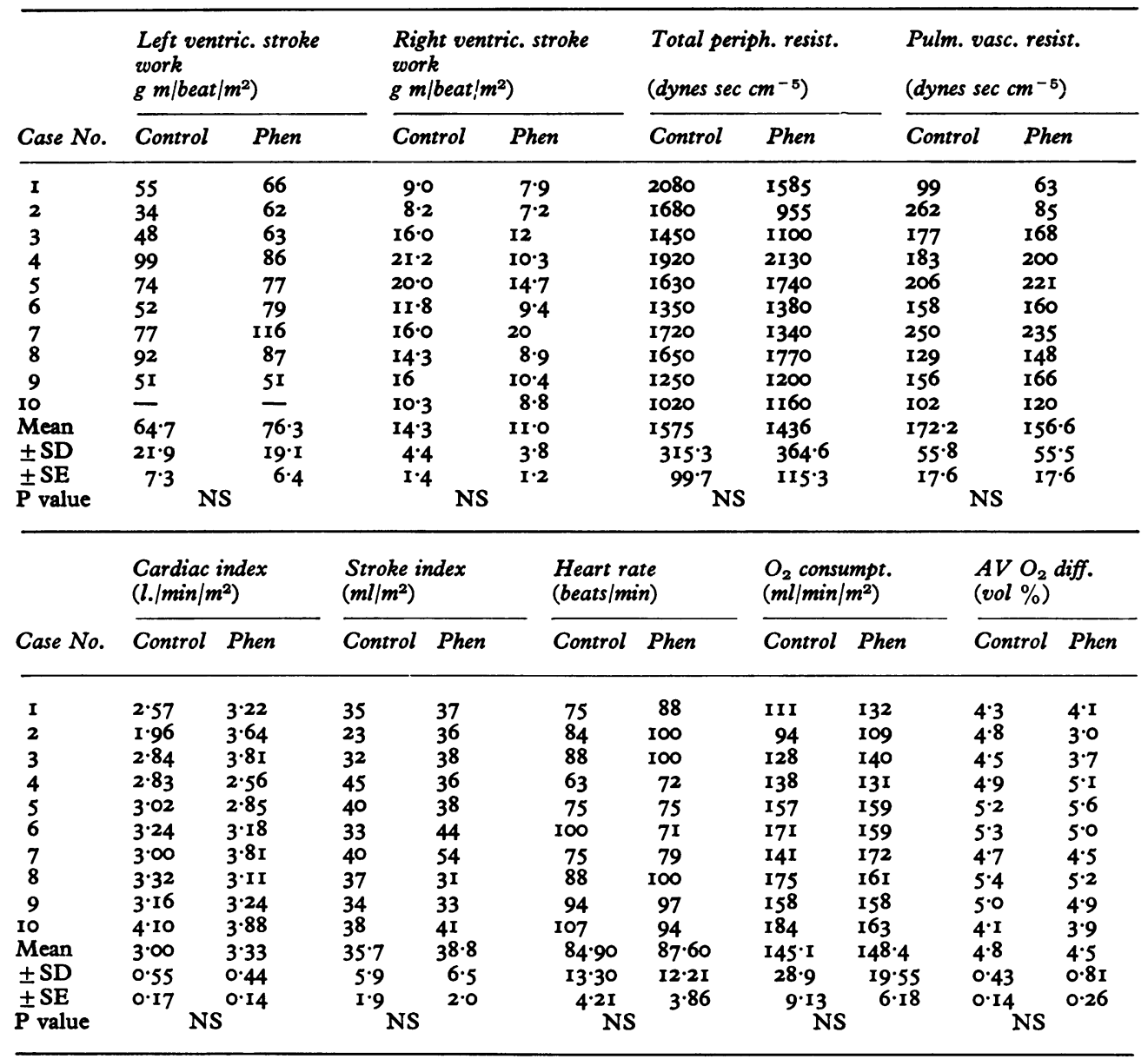

hypertensive patients and observed a rise in the cardiac index and a fall in the systemic arterial pressure. However, they also noted a reduction in the ventricular filling pressures and pulmonary artery pressures.

These varying results can be explained by the dose of phentolamine used in the two studies. The high dose of phentolamine produced predominant vasodilatation with a resultant obvious fall in the blood pressure. The decrease in the peripheral resistance led to a reflex increase in the cardiac output. The low dose of phentolamine $(0.3 \mathrm{mg} / \mathrm{min})$ that we employed in our study produced no change in the systemic pressure or peripheral resistance. This was due to the predominant inotropic effect of the drug which masked phentolamine's vasodilating action. The negligible change in the cardiac output may at first appear paradoxical. This response has, however, been explained by Braunwald, Ross, and Sonnenblick (1967). They state that the contractile state of the myocardium is not the factor that limits the volume of blood ejected by the heart in the normal person, and that an improvement of myocardial contractility by a drug with a positive inotropic effect would not be expected to increase the output in a normal subject.

Phentolamine consistently lowers pressures in the pulmonary circulation, no matter what dose is employed (Gould et al., 1969; Evans, Smulyan, and Eich, 1967; Taylor et al., 1965b). This effect, often accompanied by a fall in the pulmonary vascular resistance, has been considered evidence suggestive of pulmonary vasodilatation. The pulmonary blood volume was not determined in the study. However, Taylor et al. (1965a) determined that the acute injection of phentolamine was followed by a fall in the pulmonary artery and left atrial pressures at a time when there was a considerable increase in pulmonary blood volume. They concluded that the drug caused a direct relaxation of the vascular smooth muscles of the pulmonary bed. This is the 
TABLE 2 Continued

\begin{tabular}{|c|c|c|c|c|c|c|c|c|c|c|}
\hline \multirow[b]{2}{*}{ Case No. } & \multicolumn{2}{|c|}{$S_{\mathrm{a}} \mathrm{O}_{2}(\%)$} & \multicolumn{2}{|c|}{$P_{\mathrm{a}} \mathrm{CO}_{2}(\mathrm{mmHg})$} & \multicolumn{2}{|c|}{$P_{\mathrm{a}} \mathrm{O}_{2}(\mathrm{mmHg})$} & \multicolumn{2}{|l|}{$\mathrm{p} H$} & \multicolumn{2}{|c|}{$V_{\mathrm{E}}\left(l . / \min / \mathrm{m}^{2}\right)$} \\
\hline & Control & Phen & Control & Phen & Control & Phen & Control & Phen & Control & Phen \\
\hline I & 90 & 93 & 29 & 25 & 65 & 55 & 7.50 & 7.59 & $3 \cdot 88$ & $7 \cdot 02$ \\
\hline 2 & 92 & 92 & 42 & 35 & 62 & 63 & $7 \cdot 46$ & $7 \cdot 45$ & 3.88 & $5 \cdot 33$ \\
\hline 3 & 88 & 84 & 37 & 34 & 52 & 49 & $7 \cdot 47$ & $7 \cdot 43$ & $5 \cdot 66$ & $6 \cdot 20$ \\
\hline 4 & 93 & 90 & 38 & 36 & 68 & 60 & $7 \cdot 42$ & $7 \cdot 43$ & 3.84 & 4.05 \\
\hline 5 & 92 & 90 & 60 & 55 & 60 & 55 & $7 \cdot 48$ & 7.51 & 4.86 & 5.60 \\
\hline 6 & 96 & 94 & - & - & - & - & - & - & 6.83 & $7 \cdot 75$ \\
\hline 7 & 92 & 88 & - & - & - & - & - & - & $5 \cdot 60$ & $7 \cdot 20$ \\
\hline 8 & 92 & 94 & 34 & 3 I & 68 & 69 & $7 \cdot 55$ & 7.51 & $6 \cdot 72$ & $8 \cdot 79$ \\
\hline 9 & 91 & 91 & 36 & 35 & 63 & 62 & $7 \cdot 42$ & $7 \cdot 43$ & $6 \cdot 40$ & $7 \cdot 56$ \\
\hline 10 & 94 & 91 & - & - & - & - & - & - & $5 \cdot 73$ & $7 \cdot 07$ \\
\hline Mean & 92 & $90 \cdot 1$ & $39 \cdot 4$ & 35.9 & $62 \cdot 6$ & 59 & $7 \cdot 47$ & $7 \cdot 48$ & $5 \cdot 34$ & 6.66 \\
\hline $\pm S D$ & $2 \cdot 2$ & $3 \cdot 0$ & 9.9 & $9 \cdot 2$ & 5.5 & 6.6 & 0.05 & 0.06 & $1 \cdot 12$ & $I \cdot 38$ \\
\hline $\pm S E$ & \multirow{2}{*}{\multicolumn{2}{|c|}{${ }^{0.7}$ NS ${ }^{1.0}$}} & $3 \cdot 7$ & 3.5 & $2 \cdot 1$ & $2 \cdot 5$ & 0.02 & 0.02 & 0.37 & 0.44 \\
\hline $\mathbf{P}$ value & & & \multicolumn{2}{|c|}{ NS } & \multicolumn{2}{|c|}{ NS } & \multicolumn{2}{|c|}{ NS } & \multicolumn{2}{|c|}{$<0.05$} \\
\hline
\end{tabular}

\begin{tabular}{|c|c|c|c|c|c|c|c|c|c|c|c|c|}
\hline \multirow{3}{*}{$\begin{array}{l}\text { Case } \\
\text { No. }\end{array}$} & \multirow{2}{*}{\multicolumn{2}{|c|}{ Brachial artery }} & \multirow{2}{*}{\multicolumn{4}{|c|}{$\begin{array}{c}\text { Pressures }(\mathrm{mmHg}) \\
\text { ventricular } \\
\text { systolic }\end{array}$}} & \multirow{2}{*}{\multicolumn{2}{|c|}{$\begin{array}{l}\text { Pulmonary } \\
\text { artery mean }\end{array}$}} & \multirow{2}{*}{\multicolumn{4}{|c|}{$\begin{array}{l}\text { Left ventricular } \\
\text { lic diastolic }\end{array}$}} \\
\hline & & & & & & & & & & & & \\
\hline & Control & Phen & Control & Phen & Control & Phen & Control & Phen & Control & Phen & Control & l Phen \\
\hline I & $130 / 88$ (105) & $140 / 80(100)$ & 4 & o & 22 & 15 & 15 & 10 & 120 & 130 & IO & 6 \\
\hline 2 & I $10 / 60(77)$ & II $5 / 65(8 I)$ & 0 & 0 & 25 & 14 & 15 & 10 & 105 & 120 & 3 & 0 \\
\hline 3 & $120 / 75(90)$ & $125 / 75$ (92) & 0 & 0 & 35 & 22 & $2 I$ & 14 & 115 & II 5 & I0 & 0 \\
\hline 4 & $165 / 90$ (I15) & I70/90 (II7) & 2 & 0 & 35 & 20 & $2 I$ & 13 & 160 & 170 & 10 & 2 \\
\hline 5 & $160 / 75$ (103) & $165 / 70$ (102) & 4 & $\mathbf{I}$ & 39 & 28 & 25 & 17 & 142 & 146 & 12 & 4 \\
\hline 6 & $125 / 65(85)$ & $128 / 65(86)$ & 0 & 0 & 25 & 15 & 15 & I0 & 115 & 125 & 5 & 0 \\
\hline 7 & $150 / 80(103)$ & $150 / 80(103)$ & 2 & 0 & 30 & 26 & 20 & 18 & 140 & 150 & 5 & 0 \\
\hline 8 & $180 / 82$ (I I 5) & $200 / 80$ (120) & 3 & 0 & 30 & 20 & 21 & 15 & 185 & 200 & 12 & 5 \\
\hline 9 & $115 / 75(88)$ & $110 / 75(87)$ & 0 & 0 & 33 & 22 & $2 \mathrm{I}$ & 14 & 115 & IIO & 10 & 2 \\
\hline 10 & $110 / 80(90)$ & $125 / 82(97)$ & 3 & 0 & 22 & 15 & I4 & 10 & - & - & $\begin{array}{l}5 \\
\text { wedge }\end{array}$ & $\begin{array}{l}0 \\
\text { mean }\end{array}$ \\
\hline Mean & $(97 \cdot I)$ & $(98.5)$ & $\mathrm{I} \cdot 8$ & 0.1 & $29 \cdot 6$ & 19.7 & 18.8 & $13 \cdot 1$ & 133 & $140 \cdot 7$ & $8 \cdot 2$ & $1 \cdot 9$ \\
\hline $\pm S D$ & 12.9 & $12 \cdot 8$ & $\mathrm{I} \cdot 7$ & 0.3 & 5.9 & 4.9 & 3.7 & 3.0 & $26 \cdot 2$ & $29 \cdot 3$ & $3 \cdot 3$ & $2 \cdot 4$ \\
\hline$\pm \mathrm{SE}$ & $4 \cdot I$ & $4 \cdot 1$ & 0.5 & 0.1 & $1 \cdot 9$ & $1 \cdot 6$ & $1 \cdot 2$ & $1 \cdot 0$ & $8 \cdot 7$ & $9 \cdot 8$ & $I \cdot I$ & 0.7 \\
\hline $\mathbf{P}$ value & NS & & 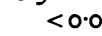 & & & & $<0$ & OI & 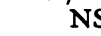 & & $<$ & \\
\hline
\end{tabular}

$\mathrm{S}_{\mathrm{a}} \mathrm{O}_{2}=$ arterial oxygen saturation; $\mathrm{P}_{\mathrm{a}} \mathrm{CO}_{2}=$ partial pressure of $\mathrm{CO}_{2}$ in arterial blood; $\mathrm{P}_{\mathrm{a}} \mathrm{O}_{2}=$ partial pressure of $\mathrm{O}_{2}$ in arterial blood; $\mathrm{V}_{\mathrm{E}}=$ minute ventilation (BTPS); $\mathrm{P}=$ significance of change between values obtained during control period and during phentolamine infusion.

most likely explanation; however, in our study the fall in the pulmonary artery pressure without a decline in the pulmonary vascular resistance does not conclusively support this contention.

Phentolamine is known to be an alphaadrenergic blocking agent. This is based on the observation that it can antagonize or even reverse the pressor response to epinephrine (Meier et al., 1949; Walker et al., 1950); the blockade thus produced is relatively transient. A mild sympatholytic action becomes manifest only with the use of very large amounts of this agent (Freis, MacKay, and Oliver, 195I). The drug also has an obvious peripheral vasodilating effect which is not blocked by atropine (Goodman and Gilman, 1955). The drug's relatively weak sympathetic blocking action as well as its antagonism to the circu- latory catecholamines cannot adequately explain the striking vasodilatation that results from its use under normal resting conditions.

Other hypotheses can be offered to explain the decline in the pulmonary artery pressure. Phentolamine by reducing airway obstruction could reduce endobronchial pressure and secondarily reduce pulmonary vascular pressures. None of our subjects had clinically evident bronchospasm, but it is not possible to exclude a direct mechanical effect on the pulmonary blood vessels mediated by bronchomotor activity. However, the comparable one-second forced expiratory volume obtained before and after phentolamine administration suggests that little change occurred in the airway obstruction. It has been shown that a reduction in hydrogen ion concentration is associated with pulmonary 
arteriolar dilatation in patients with chronic lung disease (Enson et al., 1964). In this study there was no correlation between the changes in arterial $p \mathrm{H}$ or $\mathrm{P}_{\mathrm{a}} \mathrm{CO}_{2}$ and the reduction in pulmonary artery pressure. Phentolamine could reduce pulmonary artery pressure by increasing alveolar oxygen tension. It was shown in this study that phentolamine administration had a minimal effect on the $\mathrm{P}_{\mathrm{a}} \mathrm{O}_{2}$ and the oxygen saturation.

Taylor et al. (1965a) cautioned against the use of the drug in reducing pulmonary hypertension, since in the dose they employed the decline in the systemic vascular resistance could be hazardous. However by using the low infusion rate of $0.3 \mathrm{mg} / \mathrm{min}$ this complication can be avoided.

This study suggests that the infusion of phentolamine at $0.3 \mathrm{mg} / \mathrm{min}$ may also be of benefit to patients with cor pulmonale. Further investigation of phentolamine's action in this condition is warranted.

\section{References}

Bagwell, E. E., Hilliard, C. C., Daniell, H. B., Taylor, P. L., and Walton, R. P. (1970). Studies on the inotropic mechanism of phentolamine (Abstract). American fournal of Cardiology, 25, 83 .

Braunwald, E., Ross, J., Jr., and Sonnenblick, E. H. (I967). Mechanisms of contraction of the normal and failing heart. New England fournal of Medicine, 277, 1012.

Dairman, W., Gordon, R., Spector, S., Sjoerdsma, A., and Udenfriend, S. (1968). Effect of alpha-blockers on catecholamine biosynthesis. Federation Proceedings, 27, 240.

Enson, Y., Giuntini, C., Lewis, M. L., Morris, T. Q.,
Ferrer, M. I., and Harvey, R. M. (1964). The influence of hydrogen ion concentration and hypoxia on the pulmonary circulation. Fournal of Clinical Investigation, 43, I 146.

Evans, G. L., Smulyan, H., and Eich, R. H. (1967), Role of peripheral resistance in the control of cardiac output. American fournal of Cardiology, 20, 216.

Freis, E. D., MacKay, J. C., and Oliver, W. F. (195I). The effect of 'sympatholytic' drugs on the cardiovascular responses to epinephrine and norepinephrine in man. Circulation, 3, 254.

Goodman, L. S., and Gilman, A. (1955). The Pharmacological Basis of Therapeutics, 2nd ed., p. 584. Macmillan, New York and London.

Gould, L., and Dilieto, M. (1970). Phentolamine - A new bronchodilator. New York State fournal of Medicine, 70, 2332.

Gould, L., Zahir, M., and Ettinger, S. (1969). Phentolamine and cardiovascular performance. British Heart fournal, 31, 154.

Meier, R., Yonkman, F. F., Craver, B. N., and Gross, F. (1949). A new imidazoline derivative with marked adrenolytic properties. Proceedings of the Society for Experimental Biology and Medicine, 71, 70.

Taylor, S. H., Mackenzie, G. J., George, M., and McDonald, A. (1965a). Effects of adrenergic blockade on the pulmonary circulation in man. British Heart fournal, 27, 627.

Taylor, S. H., Sutherland, G. R., MacKenzie, G. J., Staunton, H. P., and Donald, K. W. (1965b). The circulatory effects of intravenous phentolamine in man. Circulation, 3I, 74I.

Walker, H. A., Heymans, C., Wilson, S., and Richardson, A. P. (1950). The effect of C-7337 on carotid sinus reflex and on pressor and peripheral vascular actions of epinephrine and nor-epinephrine. fournal of Pharmacology and Experimental Therapeutics, 98, 33.

Wiśniewska, S. M. (1964). Prophylactic action of regitine in experimental histaminic and allergic bronchial asthma. Archives Internationales de Pharmacodynamie et de Thérapie, 149, 56. 